\title{
Liberia's Child Soldiers: Prospects and Problems
}

\author{
AMADU SESAY, OLABISI AINA, CHARLES UKEJE AND \\ ADETANWA ODEBIYI ${ }^{2}$ \\ Obafemi Awolowo University, Ile-Ife, Nigeria \\ Centre for Development and Conflict Management Studies, Ile-Ife, Nigeria
}

\begin{abstract}
The end of the cold war gave rise to expectations that Africa would benefit from the peace dividend. The euphoria was however short lived. In Liberia, a bloody civil war broke out in 1989 in which thousands of children were used as child soldiers. Surprisingly, not much is known about how they are settling back into civil society after the end of hostilities. This study tries to fill that gap by focusing on the role of social support networks in their rehabilitation. It was found that while civil society is supportive of their rehabilitation, government policies do not target child soldiers. Two NGOs, Don Bosco Homes and Children Assistance Programme, are actively involved in their rehabilitation, and have made tremendous progress in that regard. They face numerous problems: lack of space and funds, inadequate employment opportunities for rehabilitated child soldiers, and non-availability of electricity and water supply. To facilitate the rehabilitation process, there is urgent need to improve the security situation in Liberia to attract domestic and foreign investment and create jobs. It is also important for Charles Taylor to see himself as president of Liberia, and not just the National Patriotic Front, NPLF. Government should respect the fundament rights of citizens, as perceptions of Charles Taylor as a renegade has made the country unattractive to donors, thereby frustrating its post war reconstruction programmes. The international community must not abandon Liberia, but should engage it conditionally, to promote good governance and avoid another bloody contest for power in that country.
\end{abstract}

\section{Background to the Study}

The collapse of state communism in Eastern Europe, and the end of super power ideological rivalry, gave rise to a lot of optimism that the world was entering a new period, a millennium of peace and stability within and between states; an era in which Cold War conflicts would be peacefully brought to an end. In other words, Africa, like other parts of the world, was expected to benefit tremendously from post-

1

This is an abridged version of a research report on the role of social support networks in the rehabilitation of child soldiers in Liberia. The study was supported by a grant from the United States Institute of Peace.

The authors are on the staff of the Obafemi Awolowo University, Ile-Ife, Nigeria, and Directors at the Centre for Development and Conflict Management Studies, CEDCOMS, an independent non-government organisation located in Ile-Ife. Amadu Sesay and Charles Ukeje are in the Department of International Relations, while Olabisi Aina and Adetanwa Odebiyi are in the Department of Anthropology and Sociology. 
Cold War international politics, as the expected "peace dividend" and stability would enable African countries to concentrate their attention on the daunting tasks of economic development and nation-building (1).

The euphoria was however short-lived as civil strife and violent conflicts soon swept across the continent. Africa was declared the most violent continent in 1992, and accounted for 11 of the 26 major conflicts in the world in 1993 (2). A common feature of these conflicts is the use of "...small arms and light weapons such as machine guns, bazookas and rocket propelled grenades"(3), a phenomenon which encouraged large scale use, and abuse of children recruited as "child soldiers". Thousands of the combatants in the civil war in Liberia were "baby soldiers", although the country is signatory to the 1989 UN Convention on the Rights of the Child, and the 1990 African Charter on the Rights and Welfare of the African Child (4).

Although most, if not all African states signed numerous Conventions and Protocols on the Rights of the Child, "...there is considerable discrepancy .between the detailed provisions worked out by experts and the daily life of children caught up in the maelstrom of war. Abuse of children's rights by combatants seems to rise in direct proportion to the number of international law adopted to ensure children's safety...children have never before been so poorly protected...an estimated... $1.5 \mathrm{~m}$ children were killed in armed conflicts" in the ten years following the end of the Cold War (5). While such statistics are easier to assemble, it is relatively much more difficult to measure the psychological and emotional impact of war on children, for "...psychological scars sustained in early childhood do not heal easily" (6). In order to assist the healing process and empower children to contribute positively to post- war national development and nation-building efforts not just in Liberia, but also in other war torn societies in Africa, they must be given effective protection during war, and special training after the end of hostilities, particularly for those who had been involved in active combat roles. A lot of attention and efforts are directed during war towards the immediate relief of sheer human suffering (7): providing humanitarian aid, food and medicine to children, women and the aged. However, "there is a lack of continuity between efforts to relieve suffering during "emergencies"- war, and immediate post-war situations- and efforts..."(8) to promote longer-term developments, including the rehabilitation of children who had been actively involved in hostilities as child soldiers. The impact on, and consequences of violence against children in war situations have remained largely under-represented.

More specifically, how to effectively reintegrate them into post-war society, is an issue that has attracted even much less attention from researchers. "No systematic study appears to have been conducted in the relationship between the way children cope with exposure to violence and future choices, although some evidence suggests a connection between exposure to chronic fear and susceptibility to late recruitment into terrorist and armed groups" (9).

Essentially, then, the present study tried to examine the role of social support networks (relatives, parents, peers, friends, and adults), in the rehabilitation of the child soldiers in Liberia. Studies have already established the positive effects, or the stress-buffering function of social support (10). Thus the traumatised child soldiers need some buffer to prevent them from slipping either into a state of psychological disorder, or to engage in criminal acts, especially those who either lost all family members during the war, had watched them being maimed or die slowly, or had themselves participated in atrocities (11). To what extent are child soldiers getting the 
required social support in Liberia? The study tried to answer this and other important questions.

\section{Objectives of the Study}

Broadly, the study critically examined the impacts of the Liberian civil war on children, and the role of social support in their rehabilitation. The specific objectives were:

1. To investigate in detail, the motives for, and the circumstances that compelled children to get involved in the civil war as child soldiers.

2. To record in detail, the wartime experiences of 'boy' or child soldiers in Liberia.

3. To examine societal perceptions of and attitudes towards the child soldiers.

4. To assess the role of social support networks in the rehabilitation of child soldiers, i.e., the roles of parents, if alive, relatives, school principals and teachers, peers, government, etc.

5. To suggest strategies and policies that would promote the welfare of children in general and child soldiers in particular, in Liberia.

\section{Data Collection}

Data were collected with the use of In-depth interview Guides for child soldiers and Directors of Rehabilitation Centres, while questionnaires were used for peers of child soldiers, government officials and NGOs. Also, several Focus Group Discussions were held with members of the civil society, including some mothers of child soldiers, and university students. For information on the Rehabilitation Centres, data were obtained from records at each Centre, and complemented with observational data and information from key informants.

\section{The Sample}

Two groups of former child soldiers were identified: those that had been rehabilitated and those that had not been rehabilitated. Only former child soldiers in Monrovia and its environs were targeted. The researchers visited several rehabilitation centres based in Monrovia and its environs over a period of two weeks in November and December 1998. The lists of the rehabilitated child soldiers were obtained from the rehabilitation centres run by two agencies: the Catholic Don Bosco, which runs the Don Bosco Homes located in different parts of the city, and the UNICEF/USAID supported Children Assistance Programme (CAP), which also incorporates the War Affected Youth Support (WAYS) project, located in Sinkor, on the outskirts of Monrovia. Un-rehabilitated child soldiers were identified with the aid of key informants as well as directors in the rehabilitation centres.

\section{Problems Encountered in the Field}

Several problems were encountered in the field. First, was the appalling security situation in Monrovia and its environs, in spite of the formal end of the war and installation of a "democratically" elected government under Charles Taylor. Consequently, security of life and property was still tenuous in Monrovia. Second, is 
the breakdown in basic social infrastructure and services; water, electricity, sewage system, roads, etc. Monrovia has not had water and electricity supply since 1992. Residents depend on water supplied by EU tankers at strategic points in the city, while the homes of many "elite's" are lit with the aid of car batteries. Third, is the existence of what can be described as "a vicious police state" in Liberia (12). People are scared to talk openly about government and its policies for fear of being labelled antigovernment or anti-Charles Taylor, with all its dire consequences. Fourth, it was quite difficult interviewing child soldiers. Appointments had to be booked with the Directors of the Centres several days in advance. The Directors in turn had to notify the counsellors a day or two in advance. The counsellors thereafter identified and prepared the child soldiers psychologically for the interviews. This, we were told, was to avoid confronting them suddenly with either their past, or with questions and situations that could traumatise them. That took a minimum of two days. But, even when the interviews were eventually conducted, we had to tread cautiously. Even then, some of the child soldiers either refused to talk, or dodged many of the questions. Sometimes they would either burst into sudden laughter or looked blankly through the window or the door. The interviews, were expectedly, very painstaking and required a lot of patience and understanding on the part of the researchers.

Fifth, we found out that even government officials were either not available in their offices most of the time, or did not to open up to the investigators when they consented to grant the interviews. This is not unconnected with two factors. First, absence of a coherent government policy or programme, and second, fear that their comments or positions might be reported to the president. In the end, some of the projected activities could not be undertaken. For instance, it was impossible to hold focus group discussions with political leaders who were obviously suspicious of each other. Thus, we had to conduct individual interviews instead. However, we held very rewarding and revealing focus group discussion sessions with women, many of them mothers of child soldiers. They called the ex-combatants "child soyas", a name we used from time to time in this report.

\section{SUMMARY OF FINDINGS}

\section{i) Profile of Liberia's 'Child Soyas'}

The study found that there was a clear understanding and/or definition of a child soldier in the context of the Liberian civil war. The study used the definition provided by mothers of child soldiers during the focus group discussions, for it captures the essence of who a child soldier is universally. According to the mothers, a "child soya" "is an underage child who fought as a combatant during the Liberian civil war." The study revealed that majority of the former "child soyas" were males, more than 98 per cent, and only a very small number were females, about 1.3 per cent. It was not possible to locate and interview any female child soldiers because they were less willing than the boys to be identified as child soldiers.

The interviews with the child soldiers were designed to shed light on the impact of the war on them as well as the extent of their rehabilitation at the time of the interviews. We also wanted to know whether some of the child soldiers were engaged in what can be called anti-social habits before the war and during rehabilitation. The data would give an insight into whether some of the children were already predisposed to deviant behaviour before the outbreak of the war in 1989. The age of the child soldiers interviewed ranged between 8 and 18 years, although some of them 
were recruited at the age of five years. Tables 1-6 set out some of the habits of child soldiers before, during and after the civil war. Six habits were chosen: drug use, alcoholism and patronage of commercial sex workers, eating habits, gangsterism, and rape. A total of seven child soldiers were interviewed for this purpose.

With respect to drug use, it was found that 3 or 42.86 per cent of the ex-child soldiers used drugs before the outbreak of the civil war in 1989. However, 5, or 71.43 per cent admitted that they used drugs during the war, while 4 or 57.14 per cent remained hooked on drugs after the war. In terms of alcohol use, 4 or 57.14 per cent of the child soldiers said they took alcohol during the war. Patronage of prostitutes presented a very interesting picture because 3 or 42.86 per cent of child soldiers admitted to have visited brothels before the war, while $4_{x}$ or 57.14 per cent said they never visited commercial sex workers before the war. Again, only 3 or 42.86 per cent admitted they continued to visit sex houses even after the end of the war. The eating habits of child soldiers also presented an interesting profile. 6 or 85.71 per cent of the child soldiers interviewed said they were eating regularly before the war started. However, during the war, only 4 , or 57.14 per cent said they had food regularly, while 5 , or 71.43 per cent acknowledged eating regularly after the war. Again, before the war, only 3 or 42.86 per cent of the child soldiers admitted being involved in gangsterim. However, the figure rose steeply during and after the war, as 5 or 51.43 per cent of the child soldiers admitted being involved in gangsterism during and after the war. Finally, as far as rape is concerned, only 1 or 14.29 per cent of child soldiers raped before the war. However, the figure doubled during the war as 2 or 28.57 per cent admitted that they raped during the war. Only 1, 14.29 per cent, raped after the war had ended.(See Tables 1-6,Appendix 1).

The statistics presented above are very important because they indicate, if nothing else that the child soldiers' asocial behaviour rose significantly during and after the war in Liberia. These findings seem to corroborate the general belief among all the respondents that child soldiers posed serious social problems for society in post war Liberia, if not properly rehabilitated and reintegrated into civil society.

Several reasons were put forward to explain the participation of child soldiers in war. According to the mothers of child soldiers, some children joined the war because they had no food to eat outside the "bush". Others joined because of the prospects of acquiring looted property, while some enlisted to avenge the killing of a family member or members. Others fought in the war because of peer pressure and influence. Many children also took up arms as a form of security, a kind of safety net, while others did so as a result of adult control and/or intimidation (13).

It was clear that widespread poverty in the country also had a lot to do with the involvement of children in the war. It was discovered, for instance, that some child soldiers believed that taking up arms was synonymous with bidding farewell to poverty, because of the prospects of looting (14). This perception tends to correspond with the fragile backgrounds of most of the child soldiers who are mainly from very poor, subsistence farming and illiterate families (15). These were the people that bore the brunt of the collapse of agriculture and mining, the mainstay of the Liberian economy prior to the war in 1989. The collapse of the economy also saw the disintegration of the social sector and family networks, even in the rural areas. All governments in Liberia neglected the countryside, as most development projects were located in, or around Monrovia where the elite's live (16). 
Thus, having been exposed to poverty and its attendant pressures, young people were easily lured into taking up arms for what we can call pecuniary or simply 'bread and butter' reasons (17). Some of the child soldiers admitted committing atrocities during the war either in their immediate neighbourhoods, or outside of their own communities. The study revealed that those who found it difficult to return home are mainly those who committed atrocities in their communities or neighbourhoods. Some of the child soldiers admitted they were forced to commit atrocities at the initial stages of their involvement in the war by rebel commanders in order to win them over. Some admitted that committing atrocities was also seen as a rite of passage to adulthood. Furthermore, to be daring during combat, they said, also earned the "brave soldier promotion" and other sinecure privileges (18).

Observational data and the interviews showed that child soldiers posed several potent problems and challenges for post war reconstruction, rehabilitation and national reconciliation, and indeed, the peace and stability of Liberia. Our key informants told us that many of the child soldiers had been socialised for several years, into the world of violence and other anti-social behaviours at a very tender age. Having fought in the bush for many years, and having experienced prolonged exposure to arms, most of the child soldiers had been hardened by their wartime experiences. Members of the public interviewed described child soldiers as rather "loose and reluctant to conform to the most basic norms of civility". Thus, they were perceived as constituting a potential pool of miscreants who could disturb the peace unless they were successfully rehabilitated into society. One of our key informants, a former minister in the interim government of Amos Sawyer, stated that there was a high propensity for criminal activities among the child soldiers, such as mugging, burglary, rape, and even armed robbery (19). Our informants also noted that child soldiers are not only a drain on the human resources of the country if left unattended, they could constitute-- with other ex-combatants--the most potent threat to post-war peace and stability in the country. They pointed that child soldiers came into the streets of Monrovia in their hundreds with ease, in September 1998 when Roosevelt Johnson, one of the rebel leaders, made a last desperate bid to challenge Charles Taylor's hold on the country. According to the directors, even those child soldiers who were already in rehabilitation centres abandoned their tools, took up arms and fought side by side with their erstwhile "bush" commanders. And according to a senior director at CAP, "these were the very children who led the looting of the Centres that were attempting to prepare them for a future role in post war Liberia"(20).

\section{ii) General Societal Attitudes Toward Child Soldiers in Liberia}

Contrary to expectations, all sectors of civil society in Monrovia are ready to forgive the "child soyas" although those interviewed also made it clear that they would not forget the atrocities they perpetrated. Expectedly, there are still lingering memories of some of the worst exploits of the former child soldiers. Nevertheless, the spirit of forgiveness was forcefully reflected in a statement a woman made during one of the focus group discussions: "even if your child is bad, you cannot throw him/her into the evil forest." It was clear from all the interviews and focus group discussions that local communities in Monrovia have given their full support for and co-operation in the re-absorption of child soldiers into civil society. As a result, no case of rejection was recorded in Monrovia (21). Many of those interviewed were of the view that some of the child soldiers were forcibly conscripted into the war by warlords who should know better. They also acknowledged that some child soldiers committed 
atrocities because they feared for their own lives. In fact, some members of the public are philosophical about the role of child soldiers in the war. As they put it: "we have child soldiers because of the war. Before the war, there were no child soldiers". The implication of this reasoning is that much of the blame should be shifted to those who started the war in the first place, and not to the child soldiers that were merely victims of circumstances, "sometimes much beyond their own control". Some respondents even made reference to the Bible to justify the attitude of the public to child soldiers: "the Lord will restore the years that the locust have eaten"(22). Finally, it was obvious from the interviews that societal attitudes were also shaped by strong socio-cultural factors: children are highly appreciated in Liberia like any other country in Africa, and that Liberian parents, like their counterparts in other African countries, are always ready to forgive their children's misdemeanours.

The mothers' responses as well as those of relatives of child soldiers were, at that level, rather predictable. They were less bitter toward the child soldiers. They were quick to emphasise that child soldiers are also "our children, they belong to us". The mothers were unanimous in their willingness to forgive the ex-combatants. All mothers said they were actively involved in providing the necessary social buffering and support in diverse ways, to ensure their children's full integration into society once again, although they also acknowledged that the road to full reintegration was very bumpy. They pointed to the incomplete disarmament and demobilisation of excombatants as a major limitation to their quick rehabilitation. Most mothers also blamed the situation on what they described as the "premature independence" of the "child soyas", and their early exposure to "material things and other worldly behaviours"(23).

All the mothers were understandably hurt by the involvement of their children in the war, and by the roles some of them played while they were in the bush. Majority of the mothers also admitted they felt threatened by their neighbours as a result. They were unanimous in stressing that threats to their safety and security were heightened whenever there were crises in Monrovia or other parts of the country. They cited the April 1996 war, and the September 1998 clashes between Roosevelt Johnson and supporters of the government as examples. None of the mothers complained of actual violence against them. However, the psychological trauma for the parents is real and excruciating: "sometimes you feel bad", one said, "because some people ignore us, while others have small quarrels with parents of small soyas"(24).

Mothers of child soldiers also agreed that even those who committed atrocities should be encouraged to go back to school. They believed that the child soldiers can be successfully reintegrated into civil society, and that they could even be very useful citizens in the future. They felt rather strongly, too, that parents should talk and explain to the child soldiers about the need for them to change their behaviour now that they are out of the bush, and that if that was done regularly, the boys would change for the better. They also believed that other relatives in the extended African family circle could play a useful role in that regard. It is important to note, however, that even the mothers of child soldiers categorised them into two sets: those who willingly joined the factions/government troops during the war, and those who were forced into the war. According to the parents, those in the first category would be much more difficult to rehabilitate in contrast to those in the second, because they would require more attention and time to get them back in the mainstream of civil society. 
All the mothers interviewed believed the Liberian government has not done enough to help the child soldiers. As one put it: "government is not doing nothing. They do not even know their whereabouts (child soldiers)". Not surprisingly, some of the parents are also of the view that if the child soldiers were gainfully employed - a form of rehabilitation - they would change their ways. They noted, for instance, that one of the problems of child soldiers is their "premature" exposure to material things during the war, mainly through looting and even armed robbery. As such, "they have been used to spending money. Government should give them contracts that would ensure regular access to money". "They steal", one said, "because of hard times but if they have better opportunities, they can change their ways. Those who want to go to conventional schools should be provided with schools, and those who cannot should be sent to vocational schools". Only few of the women believed that "whether rehabilitated or not, child 'soyas' can still commit crimes".

Interviews with principals, proprietors and staff of some public schools in Monrovia in November-December 1998, revealed that they were all more than willing to help child soldiers get back to school as quickly as possible. They all admitted that schools took in child soldiers even when the school term was already far spent. The attitude of peers of child soldiers both in school and out of school was also favourable. None of those interviewed was unwilling to see the child soldiers in school or, to attend the same school with them. Teachers, principals and proprietors confirmed that ex-child soldiers find it easier to settle down in their new schools because their peers were most accommodating. Thus, there is a constant flow of exchild soldiers to the various schools in Monrovia and its environs, sponsored by organisations such as Save the Children Fund, SC, the Children Assistance Programme, CAP and Don Bosco Homes, DBH, among others. However, all the schools visited in Monrovia complained of government's complacency and total lack of support (25).

All the principals and teachers interviewed said they did not notice any discrimination by peers of child soldiers in their schools. They also did not report any special problems in so far as the academic performance of child soldiers is concerned. Peers of child soldiers did not object to their sisters befriending or marrying a child soldier. They were also inclined to marrying the sisters of child soldiers. Majority of the peers interviewed rationalised that there was no need discriminating against child soldiers because "they are human beings like us. Besides", they continued, "many, if not most, of the child "soyas", were forced into the war and/or to commit atrocities by circumstances beyond their own control"(26).

Some of the peers interviewed disclosed that they were not drafted into war because they were either too young or had escaped into a neighbouring country. Others claimed their parents protected them. All agreed, though, that the war had left behind bitter and awful memories, and hoped "it would never happen again". About half of the peers interviewed believed that the ex-child soldiers were blameless for engaging in the war. As they put it: "there is no smoke without fire, if the adults did not start the war in the first place, children would not have joined in the fight". Besides, many were coerced into taking up arms (27). In short, child soldiers were simply caught up in somebody's war. Significantly, some of the peers admitted that they too had handled guns, and would like to join the regular army after leaving high school. 
Almost half of the peers interviewed also admitted they had friends among the child soldiers; and were willing to be identified with former child soldiers because "they are normal, reasonable human beings, victims of circumstances much beyond their control". However, some said they would not marry a former female child soldier. But they would not mind being in the same class, sharing the same room, eating from the same plate, playing a game together, or working in the same office with a child soldier, because "some of them are as intelligent as us, and sometimes even more intelligent than we are"(28), one of them confessed. All the peers believed that the entire society and government should assist child soldiers so that they can live normal lives again. "Government", they stressed, "should enhance the existing rehabilitation work of NGOs by "building new rehabilitation Centres". They also suggested that the ex-combatants should be assisted economically "by setting up small businesses for them", ensuring their social integration, and by what one called "creating a relaxed, atmosphere for them." In short, child soldiers could still lead normal lives if properly guided by society and government.

The peers were unanimous that a lot of responsibility rested with the parents who should evolve the "rules and regulations that will guide child soldiers to become good citizens", while government should provide jobs for those that have graduated from school. As for NGOs, they should assist in providing "feeding, clothing, and so on", for the child soldiers. One point stood out clearly and consistently in all the interviews and interactions with members of civil society: their readiness to assist the child soldiers in settling down into normal life again.

\section{iii) Rehabilitating Child Soldiers: The Role of the Liberian Government}

Contrary to our expectations, interviews with government officials and opinion leaders revealed that Charles Taylor's government does not have any concrete plans that directly targeted child soldiers for rehabilitation. Opinion leaders were convinced that the government did not even know the exact number of former child soldiers in the country. It also did not allocate any resources specifically to the rehabilitation of child soldiers in its post war reconstruction programmes and budgets. We found that most government officials were reluctant to talk about this subject. However, an interview with a cabinet rank official in the Ministry of Planning, gave interesting insights into government's thinking on the matter. According to him, "the actual period of fighting in the Liberian civil war was very short; and child soldiers were only occasionally used in combat, and more often as spies"(29). Thus, given "the short duration of the war and the intensity of the war in terms of human and material loss, government policy is directed towards broad areas rather than any target group: the internally displaced, externally displaced, those who remained in their respective locations during the war, and those who fought", in that order (30).

Again, according to the minister, the issue of the child soldiers is not considered a priority by the government, because any intervention programme that favours only child soldiers or ex-combatants in general will marginalise the rest of the populace who "suffered in the hands of these gun trotting youths". Thus government prefers a "policy of non-targeted approach, that is, non-discrimination between combatants and non-combatant civilian population". The minister also revealed that government had introduced an Assisted Educational and Training Programme which is aimed at subsidising the education of child soldiers, "an important component of which is to encourage NGOs and the donor community at large, to set up Centres where child soldiers can be taught a range of vocational skills such as farming and 
small scale industrial activities, to prepare them for reintegration into civil society in post war Liberia".

However, he admitted: "government has not yet geared itself towards specifically helping child soldiers" because to "openly support any initiative in favour of child soldiers is to glamorise ex-combatants as a generic group. Government", he said, "would not like to be seen encouraging the 'tyranny of the minority."' Besides, "assisting child soldiers openly could "expose them to society's wrath", as it would "easily remind the society of the atrocities the kids have committed. These are the considerations", he went on, "that are strengthening government's resolve to dismantle institutionalised frameworks, including orphanages, preferring societal healing. After all", he stressed, "in traditional African society, no child is an orphan. It is better to strengthen the family", he stressed. Accordingly, "government introduced a Family Relocation Scheme starting with Monrovia in the fourth quarter of 1998, as well as a micro credit scheme with an initial capital of 8 million Liberian dollars (roughly $\$ 19,000)$ to provide a revolving loan to women, women's co-operatives and to families"(31).

Nonetheless, interviews with opinion leaders in Monrovia revealed that the micro-credit scheme was not an effective way of enabling families to cope with the strains and stresses of reintegrating child soldiers in post war Liberia. The opinion leaders criticised government's entire policy towards child soldiers because "members of the public were already supportive of their reintegration into society". According to the Chairperson of the Liberian Women Initiative,

Government has done virtually nothing to assist them (child soldiers). Government, frankly, lacks the fiscal wherewithal and the political will. Besides, it seems to have found itself overwhelmed by the magnitude of reconstruction and nation-building programmes that needed urgent attention...even when child soldiers are trained in rehabilitation centres and homes, such newly acquired skills have not been used efficiently thereafter because there are no opportunities in the country (32).

Finally, a director at the CAP rehabilitation centre noted: "there is no real resolve on government's side to implement programmes for child soldiers or, to support the efforts of international organisations such as UNICEF", in sustaining their rehabilitation activities. His conclusion is that government has been "partially indifferent to the plight of child soldiers."

What is responsible for the government's attitude towards the child soldiers? According to one of our informants, one major limitation is the "inability of Charles Taylor to successfully transform himself from a warlord into the national leader of a "democratic" Liberia". Furthermore, "government is itself in the habit of recruiting child soldiers both into the regular army and Special Forces set up by Charles Taylor, such as the Special Security Unit (SSU)" based in the presidency. "This unit", he said, "is made up almost exclusively, of former child soldiers, and are dreaded because of their near fanatical loyalty to the "Pa"', and the apparent immunity that they enjoy. "This is the crux of the matter"(33). The present government in Liberia, based mainly on impunity, as it were, is unable to attract external funding to execute its post war reconstruction programmes, including the rehabilitation of child soldiers. According to our informant, "this situation has led to double speak on the part of government, with the slogan: "we are moving Liberia out of Monrovia. What that simply means" 
our informant continued, "is that government does not intend to do anything about the plight of Liberians in Monrovia, including child soldiers, period"(34).

The truth of the matter, though, is that government is also not able to attract external funds "because of its poor human rights record, and because Liberia is still seen as a pariah in the international community especially by its neighbours, who blame Taylor for exporting war to their countries. According to this theory, which is rather plausible, "Taylor is perceived in diplomatic circles as a renegade, antidemocratic and corrupt, a man whose actions are characterised at all levels, with impunity"(35). This point needs stressing because external assistance to African and other developing countries in the post Cold War era is heavily shrouded in political conditionality: respect for human rights, good governance, accountability, and so on. But these are also yardsticks on which the Liberian government scored very low. "Lack of confidence in the president and his government", he said, is "evident in the fact that although Taylor organised a donors' conference in Paris in April 1998 to sell his post war reconstruction programme then estimated at $\$ 400 \mathrm{~m}$ dollars, donors' pledges totalling $\$ 200 \mathrm{~m}$ had not been redeemed by December 1998". "More importantly", he stressed, "government itself cannot raise its own matching funds of $\$ 200 \mathrm{~m} "$.

He lamented that the situation would not change for some time for several reasons. First, allegiance is owed not to state institutions, but to Charles Taylor. Second, Taylor was dispensing state resources and sinecure opportunities to only the favoured few that are committed to him personally, and to the defence of his regime. He regretted that in post war Liberia, "the authority of the state and its institutions are merely an embodiment of one person, Charles Taylor, whose power and authority writ large. Not surprisingly", he said, "whatever the president is not interested in, becomes a "no-go area" for other government institutions and functionaries. Under the circumstances", he concluded, "it is hardly surprising that the rehabilitation of child soldiers is a not a priority of the government of Charles Taylor"'(36).

\section{iv.) The Role of Non-governmental Organisations (NGOs)}

In the absence of a firm and coherent government policy on the reintegration of former child fighters into the rest of society, the responsibility has rested on the shoulders of private local and international agencies. This section examines the activities of these organisations, their achievements, problems and prospects. Two agencies, the Catholic owned Don Bosco Homes or Centres, and the Children Assistance Programme (CAP) which also incorporates the UNICEF/USAID funded War Affected Youth Support (WAYS) project, are singled out for attention because they are the ones that are seriously engaged in the rehabilitation of child soldiers in Monrovia and its environs (37). The findings are based mainly on field interviews with their Directors and other senior officers

\section{a.) Don Bosco Homes (38)}

Don Bosco Homes, DBH, is a Roman Catholic organisation named after Don Bosco, a popular Catholic priest who worked mainly with street children in Italy in the 19th century. The broad mandate of Don Bosco Homes is to cater for children in difficult circumstances: "unaccompanied children, ex-combatants, orphans, street children, children in problem with the law and other cases arising out of the behaviour of juveniles from different social and psychological backgrounds"(39). In short, "to 
reach out to those children who for one reason or other had become literally "unwanted" in society." Thus, unlike CAP/WAYS, Don Bosco does not specifically target child soldiers. The DBH Centres were opened in 1993 in response to the growing needs of thousands of disadvantaged children in Liberia in the aftermath of the civil war, and provides services such as: "night shelters, rehabilitation homes, feeding, medication, formal and informal education, parental care, clothing and security"(40) to children in difficult circumstances. The main thrust of the rehabilitation process can be described as psychological: "to make the children feel that they are not unwanted in spite of whatever state they may find themselves in". In other words, Don Bosco Homes "help children rise from the junk piles of deprivation to live normal, productive lives."(41) At the peak of its activities, Don Bosco had over 2000 boys and girls (42).

Don Bosco has five main Centres in Monrovia: the Monte Carlo Training Centre, located in down town Monrovia, and the rest at West Point, Ashmun Street, Benson Street and Sinkor. We visited all the Centres during the field trip and spoke with the officials and residents. Don Bosco is divided into four broad departments, each of which is headed by a co-ordinator as follows: a) Welfare Department, charged with responsibility for legal aid, family tracing, street contacts with children, documentation, reintegration, reunification and follow-ups. b) The Care Services Department which looks after accommodation (hostels/homes), feeding, clothing, parental care, formal education, etc. c) The Mental/Physical Health Department, which takes care of counselling and medical needs. The Department is sub-divided into two sections, namely: the counselling unit, which looks after the mental health of the children, and the physical health unit, which operates clinics for the treatment of diseases and general illnesses. d) The Education/Training Department, which provides technical education, tools for trainees, job training and employment opportunities (43).

Interviews with the Head of Don Bosco in Liberia, Reverend Father Joe Glakin, and all its directors/co-ordinators, revealed that the Organisation accepts children in all difficult circumstances. However, once child soldiers are taken in, they go through a rigorous regime of retraining to "prepare them for a useful life in civil society". There are no special criteria for admission into the Homes other than genuine needs. There is also no discrimination on the basis of sex, religion, age, ethnic background and/or other socially defined categories.

From the interviews held with officials at the Centre, it was found that Don Bosco's rehabilitation programme exposes child soldiers to vocational skills such as carpentry, shoe making, furniture making, etc. These vocations are however only for child soldiers who are not already in formal schools. The Centre, we were told, "encountered serious initial problems in dealing with child soldiers" in part, because of their links with peers outside, especially those in the regular army and the special presidential units, and those with their erstwhile bush commanders (44). Some child soldiers also had access to firearms from several sources, including their peers in the armed forces and special security agencies. The consequences are particularly problematic for the rehabilitation homes. For instance, a Director at the Monte Carlo Centre told the researchers that a Welfare Officer once sent out to look for child soldiers on the streets of Monrovia found that most of them had guns, and that many of them had also participated in the September 1998 uprising. "It was therefore not only difficult but also dangerous for Counsellors to approach such children"(45). 


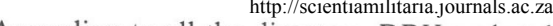

According to all the directors. DBH undertakes to place former child soldiers in schools if they so desire, after they have been rehabilitated sufficiently. Don Bosco also tries as much as possible to provide them with jobs, and does engage some in its Centres as mechanics, carpenters, plumbers, office assistants, etc. There are also follow-up services. For example, for child soldiers in schools, its officials monitor their progress "by visiting the schools and collecting their report cards on a regular basis". Again, as most of the children are separated from their families, DBH provides monthly allowances to the fully reintegrated child soldiers commensurate with basic needs such as tuition, feeding, rent, etc., "as a way of keeping them from the streets, but only for a limited period of time".

One of the DBH Centres located in Sinkor, on the outskirts of Monrovia--not far from where the researchers stayed--was closely observed using an Observation Schedule. Our observation revealed the following: Only 8 former child soldiers between the ages of 15-16 were at the Centre, which had a clinic with 2 full time nurses. There was portable water although from a well, and electricity from a small stand by generator, which is switched on for several hours during the day. There was a water closet toilet system, using water from the well. There were 4 children in a room, while each room had bunk beds. The Centre had problems with the drainage system as well as with refuse disposal. It was discovered that the children have their lunch at 2 O'clock daily, on a menu of rice and burger wheat. The general environment was clean, quiet, and safe. The cleanliness of the environment is the responsibility of all the children, and it forms part of their daily chores. The boys interact with each other well. Those whose families could be traced had a good rapport with them, and have access to their family members once in a while. Visiting hours are usually 2-5 P.M. on Saturdays. The pupils wake up every day at $6 \mathrm{~A}$. M to clean the environment and cook their breakfast before they settle down to the day's work. There is time for recreation although a dearth of facilities in that regard was noticed. Bedtime is 8.P.M. everyday.

The morale of the children and staff was very high, although the absence of certain needs and facilities such as electricity, television and video tended to negatively impact on the work of the Centre. However, the safety of all the children was assured, and those we interacted with confirmed they did not fear for their personal safety while at the Centre. Our interaction with the children and the Welfare Officer also revealed that students come into residence via a variety of channels: through other pupils, peers, relatives, friends, or by simply being picked up on the street by officials of DBH. However, child soldiers must be less than 18 years.

The interviews revealed that the Don Bosco faces several problems. The major ones include: a) lack of accommodation space to take in the ever-increasing number of children in need of its services, b) lack of trained staff especially in the area of social welfare. The Directors complained of the small number of staff with requisite skills in this vital area compared with the large number of children they had to deal with. "This invariably means that officers do not give the children enough time. Thus, contact hours between the officers and the children are very low". c) Inadequate financing. d) Absence of municipal facilities such as transport, water, electricity, medical, etc. In fact, this is a common complain in all the Centres. We were told that the problem started in 1992 during "Operation Octopus," when Charles Taylor, then leader of the rebel National Patriot Front of Liberia, NPFL, made a futile attempt to take the capital by force. In the process, important municipal facilities such as water, electricity, sewage system, roads, were destroyed. Unfortunately, the official 
lamented, "government has not been able to restore these services". Monrovia has not had electricity and water supply since 1992"(46).

In spite of these limitations, we observed that the programmes of the Don Bosco Homes were having a positive effect on their beneficiaries. This was clear not only from the children we interacted with, but also from a Don Bosco Homes house magazine's letters page titled: Reflections: Tales of Gratitude from the Heart. Two letters are reproduced below because they say it better than anyone else can.

My name is Garvin .B. Nelson. I lived in Kakata. I played with my friends and went around with people. Then, I took up arms to fight in the Liberian war. After I disarmed, I was permitted to go to school to become someone tomorrow. Save the Children took me to the Office of Don Bosco Homes. Now, I am in Virginia going to school, eating three times a day. I am feeling all right. I wish all my friends in Virginia love and happiness. I thank Don Bosco for helping me (47).

My name is Konah Flomo. The UN brought me to Don Bosco Homes. They took me from Kakata. First, I was at a Catholic hospital taking treatment. My ma is dead and don't know where my pa is. I eat well. The nurse treats me good and everything satisfies me (sic)...Don Bosco Homes sends me to school, and I am in K-2 class. I love Fr, Joe and the nurse and all those who help me. I pray that their work may prosper. I hope to help Don Bosco Homes when I am old enough ( $\mathrm{sic})(48)$.

\section{b) The Children Assistance Program (CAP)}

This is the only wholly local organization involved in the rehabilitation of former child soldiers in Monrovia. Like Don Bosco, it does not cater exclusively to the needs of child soldiers, for its mandate is broad enough: to provide various forms of social welfare services and assistance to 'disadvantaged' Liberian children (49). In 1996, CAP entered into an agreement with UNICEF as implementing partner for the USAID/UNICEF funded War Affected Youth Support (WAYS) project. Under the agreement, the Centre was able to "operate three mini national Centres with a total enrolment of 409 trainees". The curriculum encompasses several disciplines: auto trade, building, cosmetology, ceramics, furniture making, graphic arts, home economics (pastry, food preservation), soap making, tailoring, tie-dye, shoe making, blacksmithing and agriculture (50). In all, thirteen trades are available at the Centre. The USAID/UNICEF project coincided with what the directors called the "Third Cycle of the Centre's activities". We were informed that unlike the previous two cycles, trainees for the third must have major and minor areas of specialisation. According to the officials, out of the 13 trades available, a trainee is allowed to select a minor area of specialisation either in graphic arts, tie-dye, and soap making or ceramics. It is possible that this arrangement is designed to increase the job opportunities of those who would like to work in the formal sector of the economy, while at the same time enhancing the income generating chances of those who would opt to be self employed. CAP, we were made to understand, had a staff complement of 7 , all of whom are graduates.

It was evident from our interactions with some of the students, that the Centre was making a positive impact on its trainees. The researchers were privileged to witness the end of year exhibition mounted by pupils in late December 1998, and 
were really impressed with the quality of the products on display as well as the commitment of the children to their projects. They were all very proud to take us round their stalls, and to answer any questions posed to them (51).

Three sets of interviews were conducted at CAP: One with the Directors and the other two with child soldiers and their peers. The directors were all in their late 30 s, and graduates of different academic institutions in Liberia. Some directors said they did not only lose close relations during the war, but also valuable properties. It was obvious from the interviews that they were convinced the mandate of the Centre extended beyond the rehabilitation of child soldiers and other war affected children. According to one of the directors, "CAP/WAYS gives a broader understanding and interpretation of the tasks that must be done if Liberia were to reclaim its position in the comity of civilised nations. That means that the CAP's activities must involve rebuilding the moral values of society which were destroyed during the seven-year war." As far as the children are concerned, this "involves undoing the ugly orientation which the child soldiers were given during the war." But that would take a much longer time for which the Centre did not have resources. "What the Centre does, then, is to rehabilitate the child soldiers sufficiently enough for them to realise the enormity of their past activities and to set them on the road to leading normal lives once again" (52). With that, they hoped that the process of their reintegration into society would also include a reorientation of their moral values. All the directors interviewed strongly believed in the merit of what they were doing.

Admission to CAP is not based on parochial criteria such as county of origin, sex or religion, but purely on need. But unlike Don Bosco, CAP/WAYS accepts trainees up to the age of 21 . However, majority of those in the 21-year age bracket are not child soldiers. The rehabilitation usually takes about nine months because "training in technical skills requires time and most of the trainees are illiterate." After the first two months the children are evaluated using standardised tests, and every other two months thereafter. "Those who fail must continue the training until they are able to pass the tests. That way, the Centre is satisfied that the children are ready to meet the challenges of the world outside (53).

The researchers observed that like $\mathrm{DBH}, \mathrm{CAP}$ also involves rehabilitated child soldiers in the day to day running of the Centre--they cook, clean up the environment and do other chores as, and when required. They further noted a group of trainees painting the Centre in December, a few days to the annual exhibition of their works to the public. Those who are employed are usually given a stipend of $\$ 100$ paid in two instalments. CAP/WAYS, like Don Bosco Homes, makes some effort to place reoriented child soldiers on jobs and in schools. They also have a follow-up programme whereby those sent either to schools or put on jobs are monitored to assess their readjustment process. The monitoring, we were told, revealed that at least over 60 per cent of their graduates "do perform excellently on their jobs or in school". The Centre has what is called a "visiting extension component". The main concern of this section is to assist those graduates who want to be on their own to establish smallscale businesses, and "to teach them how to continue on their own thereafter". To make reintegration relatively easier, UNICEF provides USD\$100 and a tool kit to each graduate. Furthermore, CAP tries to secure contracts that they can execute and earn an income. Besides that, there is what is called CAPLINK, which follows the former child soldiers and indeed, other graduates, wherever they may be to see what they are doing and how they are coping with their new lives and status. As for those who are placed in formal schools, there is also a follow-up programme specially 
designed for them, which is run mainly by counsellors and those in the Adult Literacy Department. At the time the interviews were conducted in early December 1998, the Centre had settled a total of 25 former child soldiers in regular public schools: 13 in Buchanan and 12 in Monrovia. According to the directors, the performance report on the 25 children is mixed: while some were said to "be doing very well in their school work, others are not, while others are performing below average." Irrespective of their performance, CAP takes care of their school needs but parents, where they can be found, are required to take over their responsibility after the first two years (54).

The directors admitted having cases of "readmission", but said they are very few, and usually involve much younger children between the ages of 8-10. These children usually return because they "feel they are too young to cope outside here, and we don't have to discourage them"(55). It is not clear, however, what the returnees do or for how long they are allowed to remain at the Centre given the limited spaces available. Unlike DBH, CAP/WAYS does not have a residential programme, so all the children come in the morning and close at 5 P.M. Again, unlike Don Bosco, CAP does not maintain contacts with the trainees once they have closed for the day, until they return to school the next day. The directors complained about the obvious shortcomings of the system, but said, "there is nothing they can do" since accommodation facilities are not available at the Centre. They experience problems with child soldiers at two broad levels: first between child soldiers and other children, and second, between child soldiers and members of staff. With regard to other child soldiers and/or peers, "child soldiers do initially engage in fights although not all the time". With teachers/instructors, "child soldiers tend to be insulting, abusive and even attempt to fight the teachers". Such behavioural traits are only manifested in the first few weeks or months of their admission, though. But the directors understood the plight of the child soldiers, and as one put it, "their behaviour is simply a manifestation of the lingering effects of the war, and the attendant destruction of the family system and moral values, which had resulted into a palpable lack of respect for elders in society"(56).

The directors admitted that the rehabilitation programmes had made a big difference in the lives of the child soldiers. The senior director summed up the impact of the Centre on child soldiers thus:

Before they came in, they had been used to doing things least expected of children of their age, such as stabbing each other, multiple rape, killing, etc. After the war, such incidents remained, and these include killing as a pastime. Many of the child soldiers also lacked respect for anything or anybody. Today, rehabilitation programmes have, for instance, improved the civic consciousness and community spirit of the kids. Because rehabilitation programs are often service oriented, they have taken the kids away from the street, reduced crime rates and dependency. Many of them have graduated and have gone on to be good craftsmen and women (57).

In spite of this significant achievement, the Centre has had to cope with a lot of problems and limitations. First, is what a director described as "non-sustainability of resources." We were told that finance was a big problem, and that at the time of the interviews in December 1998, the Centre had funds for only one programme, the WAYS project that was being sponsored by USAID and UNICEF. Even so, they complained that the money was small, compared with the magnitude of the work to be done. The financial situation also affected the level of salaries and emoluments 
payable to instructors and teachers, and by implication, their morale and commitment to their work. As such, those who decided to stay on their jobs did so mainly "for humanitarian reasons and not for what they were paid as salaries"(58). The second problem identified was logistical, that is, lack of transportation and other enabling municipal facilities such as modern toilets and other sanitary facilities, electricity, pipe borne water, and general insecurity of properties (59).

The third problem is related to the first two: uncertainty about the future. Although a senior Director told the researchers that the Centre "had embarked upon an aggressive drive to raise funds to continue this laudable and popular initiative", he was also quick to add that CAP "might just be on the fringe of destruction if the current level of funding stops or is tampered with"(60). All the directors lamented government's lack of interest in what they were doing apart "from moral support and guidelines". The fourth problem is lack of space to accommodate the growing number of children in need of its services. The senior Director emphasised that the space problem can only be tackled effectively if "there are funds so that, for instance, more Centres can be opened in Monrovia and other parts of the country".

The needs of the Centre were, expectedly, also many. All the directors said a standby electric generator would significantly improve the quality of life for both staff and trainees. They also longed for what they described as "a well-equipped training Centre with modern facilities like any good vocational training school would have." They believed that USD $\$ 100,000$ would be enough to "solve all these problems. We can build our own modern complex with such money"(61). The directors regretted that they do not have access to a single computer at the CAP/WAYS. They were convinced that if they had a computer, their work would be enhanced significantly, especially in the "storage and retrieval of data on the child soldiers and other trainees". With a computer, they could also "prepare a directory of all graduates and their locations in different parts of the country. That would make it easier to follow-up and monitor them". Besides, such information could also "form the base line for the alumni association which had just been formed by former trainees"(62). Finally, shortage of staff was another important problem identified by the directors. They all complained about inadequate staff given the magnitude and importance of their work If they have more staff, "instead of one instructor teaching carpentry to all the trainees, it should be possible to have two or three instructors teaching the same trade"(63).

\section{Obstacles to the Rehabilitation of Child "Soyas" in Liberia}

Some of the obstacles to the successful rehabilitation of child soldiers in Liberia have already been identified in the various sections above. Thus we will concentrate on those directly or indirectly related to the present Liberian State, its political system and what we can call the leadership idiosyncrasies of President Charles Taylor.

The interviews and discussions with our key informants revealed that Liberia is still largely a shadow state (64). Consequently, it is unable to effectively carry out the duties and responsibilities of a normal functioning state. It was clear from all the interviews and focus group discussions that government has not taken the necessary steps to revive the economy, and lacks the means to do so. Furthermore, government's own financial recklessness and corruption has tended to put off foreign investors and donors. Our informant pointed out that it would take a long, long time before any 
semblance of normalcy is restored to the national economy and social infrastructure, and until that is done, the rehabilitation of ex-child combatants and for that matter, the entire nation, will remain half-hearted and largely rhetorical.

All the respondents are conscious of the fact that full rehabilitation for child soldiers will also depend on the availability of job opportunities in the country. But they noted that at the moment, opportunities are so few that they cannot even accommodate the relatively few child soldiers that have been successfully rehabilitated. According to our informants, the unemployment rate in Monrovia where close to half of the population is now located, is above 60 per cent. Besides, even those who claim to be self-employed are in actual fact in disguised unemployment. They pointed to the fact that major streets and road junctions in Monrovia are strewn with moneychangers - mainly between the ages of 15 and 25 - in support of this claim. It will be recalled that lack of employment opportunities was identified by all the directors of rehabilitation Centres as a major constraint; it slows down the rate of admission, and prolongs the training period for ex-child soldiers. In addition, even those ex-child soldiers who are predisposed to seeking help from the Centres do not do so because they are not sure of gainful employment after their period of training (65).

Our informants averred that although there is a fledgling private sector in the country, "it has been taken over by Indians, Pakistanis, Lebanese and Syrians". Some of them "were close allies of Taylor's NPFL during the civil war, and might even be business partners"(66). Observations revealed that in Liberia, as it is the case in neighbouring countries, these enterprises are mostly family owned, and do not offer much job opportunities to the indigenous labour force. Our contacts confirmed that government does provide employment to child soldiers, but that those employed are in the main un-rehabilitated, and are absorbed either directly into the Armed Forces of Liberia, the President's Special Security Units, or simply sent to the war front in neighbouring Sierra Leone, to fight side by side with rebel RUF and AFRC junta forces. It was clear from the focus group discussions, the interviews and briefs by key informants that thousands of child soldiers were involved in the civil war in Sierra Leone. Our key informants also drew our attention to the "neat and very young soldiers in blue 'tie and dye' camouflage uniform with AK 47 assault riffles" slung across "their relatively young shoulders". They "are members of the elite Special Security Unit, SSU, charged with protecting the President". They are also to be found in the president's "long and luxurious motorcade". We were reliably informed that the young soldiers are not only ruthless in protecting the "Pa" or "old man" (Charles Taylor), but also enjoy a lot of immunity. Our informants concluded that "using child soldiers in this way is one important reason why the Liberian government has not attended to their full rehabilitation and reintegration into civil society"(67).

All the respondents identified the failure of the disarmament and demobilisation process as provided for under the Abuja Accords of August 1996, as a serious limitation to the rehabilitation of child soldiers in the country. They pointed out that some child soldiers did not hand over their weapons, while the command structure between them and their former rebel commanders was left intact. This situation is responsible for the desertion of rehabilitation camps by child soldiers at the slightest opportunity, to rearm and fight side by side with their factions. Our informant singled out the "April 1996 war for Monrovia", and the September 1998 uprising triggered by Roosevelt John, to buttress the point. 
Lack of government support has also been identified as a major obstacle to the full reintegration of child soldiers into civil society. For instance, although the Ministry of Planning talked about "strengthening the family" as an indirect way of providing social support to child soldiers through a micro credit scheme, the measure was ineffective. First, the money voted for it was too small, 8 million Liberian dollars or approximately $\$ 19,000$. Second, only a handful of families benefited from the scheme. Third, there were no hard and fast criteria for dispensing the money. Consequently, they lamented, "even the few that benefited from the scheme were also families with strong connections with the government"(68).

Our study revealed that the rehabilitation of child soldiers has also been hampered indirectly by the perception of Charles Taylor as a renegade leader by the international community. This perception is due to several factors: first, is the inability of the Liberian president to transform himself successfully from a rebel leader, and cut the image and stature of a national and international figure. Second, is the wide spread impunity in government's policies and actions, which have led to loss of confidence in his administration both at home and abroad. Third, is what our informants described as 'gross violations of human rights' by the government in Monrovia. "To crown it all", they said, "there is no respect for laid down rules and regulations in the behaviour of the president, his officials and government apparatus at large". The net result of all this, is that in "his government easily invokes 'donor fatigue' abroad"(69). Thus, it has not been able to raise funds for post-war reconstruction, which includes the rehabilitation of child combatants.

Another handicap in the rehabilitation of child soldiers identified during the interviews is the small number of civil society organisations that are involved in the rehabilitation process in Monrovia. At the time of the fieldwork in late 1998, only two organisations were directly involved in the rehabilitation of child soldiers in Monrovia and its environs., Don Bosco and CAP. Perhaps if the political climate were to be more congenial, other NGOs in this critical area of need would have been attracted to the country.

\section{Recommendations}

The interviews as well as published reports about the Liberian war showed that all sides violated international statues by enlisting children into their forces. (The story is the same in neighbouring Sierra Leone). Consequently, the international community should bring pressure to bear on all African states, indeed, all developing countries, to respect the rights of children as enshrined in international covenants to which they are parties, by ensuring that children are not used as soldiers in future wars. As a matter of urgency, the age threshold for recruitment to the regular armed forces and rebel soldiers should be raised to 18 years. Furthermore, stiff and comprehensive political and economic sanctions should be brought to bear on African governments and rebel movements that violate existing international conventions.

There is urgent need for improved security of life and property in Liberia in general and Monrovia in particular, to attract both local and foreign investment. The poor security situation in Monrovia is certainly a disincentive to investors. However, inadequate security especially in Monrovia and its environs is directly and indirectly tied up with the issue of child soldiers. For as long as majority of them remain unrehabilitated and unemployed, they will continue to constitute a potent source of threat to internal security. On the other hand, government's ability to attract 
investment funds would largely depend on the security situation in the country. Thus, it is in many ways a vicious circle. But it is plausible to assume that a determined effort by government to tackle the issue of child soldiers would generate enough good will and confidence both at home and abroad, while also improving the security situation in the country. The Liberian government should therefore see a direct link between national security and post war reconstruction, including the rehabilitation of former combatants. After all, unless Liberians feel safe and secure in their homes, at work and in the streets, they would not contribute effectively to national reconciliation and reconstruction efforts. It is only when there is an enabling security environment that people can give their best in all human endeavours.

The government of Charles Taylor should, as a matter or priority, make a determined effort to improve its human rights record. This is imperative if it is to win international confidence and attract the badly needed foreign help. In a world in which foreign assistance is tied increasingly to issues of good governance, transparency and human rights, the Liberian government cannot hope to attract the -external funds needed for post war reconstruction unless it can convince prospective donors that it respects basic human rights, and that it is accountable to the people of Liberia for all its actions, both in the domestic and external realms.

The international community, donor agencies and governments in particular must not abandon Liberia. Rather, they should pursue a policy of gradual but conditional engagement with the government of Charles Taylor. It is only in that way that they can hope to influence not only its policies, but also the orientation of Charles Taylor, its president, and in the long run, avoid another violent eruption in that country. Perhaps now is the time for such engagement. That way, it can be transformed into a stable, peaceful, and prosperous country respected by its neighbours and the international community at large. That would also prevent the opposition from resorting to the use of Force, to challenge President Taylor's authority. To be sure, and for now at least, the opposition is prostrate but it has not given up the contest for power in Liberia.

Perhaps all hope is not yet lost. The fanfare that surrounded the open destruction of thousands of weapons and millions of ammunition by the Liberian government in the presence of the Nigerian Head of State, Olusegun Obasanjo, and Tejan Kabbah of Sierra Leone in early July, 1999, is surely an attempt by Taylor to symbolically sever not only the links between his government and the rebels in Sierra Leone, but also the image of a renegade president which he cut in the first two years of his administration. As long as he is sincere in his determination to restore normalcy to his country, the rest of the world should encourage him through constructive engagement.

Finally, the international community - at the sub-regional, regional and global levels - should begin to pay more attention to the background conditions that led to situations like those in Liberia before the war in 1989. Perhaps it is time for the UN, regional and sub-regional organisations to come out openly in favour of zero tolerance for coups, coup makers and their governments in Africa. That way, potential coup makers and other destabilising forces, would be given clear signals that their governments and/or representatives would not sit side by side with those of legitimate and democratic governments at international forums. It is gratifying to note that the July 1999 OAU summit in Algiers has already made a move in such a direction. West Africa, under the auspices of the Economic Community of West African States, 
ECOWAS, and with support from the sub-region's super power, Nigeria, is also inching slowly towards a zero threshold. Donor agencies should encourage such a trend in the continent and elsewhere in the developing world.

More over, it is time for donor governments and agencies to sincerely insist on good governance, transparency, accountability and respect for basic human rights as criteria for engaging African governments. Those that do not meet the requirements should be sanctioned. It is obvious from the Nigerian example that sanctions do work if the international community is determined and sincere enough to make them work. That should not be too difficult in a post Cold War international system. It is conceivable that sincere and concerted action by the international community in Liberia would have moderated the rampant corruption and ethnically centred governments (especially after the 1980 coup), which ruled that country for many years, paving the way for the disastrous civil war and eventual collapse of the state, leaving behind untold human suffering and misery. African leaders should also learn lessons from history and contemporary times. There is now no viable and credible alternative to democracy and good governance. A government that is centred on the will of the people is much more secure than one protect by a million guns and paid assassins (70). Finally, in an age of increasing globalisation, the world should no longer be divided into zones of peace and prosperity on the one hand, and on the other, zones of conflict, violence and human misery. Liberia must not be allowed to go through a second civil war, for as Barry Munslow has rightly observed: "...if human survival is left in question then the seeds of further conflict may be nurtured and will grow in fertile soil"(71).

\section{Notes and References}

1. For more on the impact of the end of the Cold War, see Sola Akinrinade and Amadu Sesay (eds.), Africa in the Post Cold war International System, London: Frances Pinter, 1998, United Nations Institute for Research in Social Development, UNRISD, States of Disarray: The Social Impacts of Globalization, Geneva: UNRISD, 1995, Thomas G. Weiss and Meryl A. Kessler (eds.), Third World Security in the Post Cold War Era, Boulder: Lynne Rienner Publishers, 1991, Oliver Furley and Roy May (eds.), Peacekeeping in Africa, Aldershot,: Ashgate, 1998, and Yusuf Bangura, The Search for Identity: Ethnicity, Religious and Political Violence, Geneva, UNRISD, Occasional Paper, No. 6.

2. World Military Expenditures, Washington, D.C., World Priorities, $15^{\text {th }}$ edition, 1993, p 3.

3. Louise C. The Social Impacts of Light Weapons and Small Arms Availability and Proliferation, Geneva, UNRISD Discussion Paper, No.59, 1995, p1.

4. See Buren, Van G., International Law on the Rights of the Child, London: Save the Children Fund (SC), 1994.

5. UNRISD, States of Disarray, p110.

6. Siefel .M, The Challenge of Peace: Rebuilding War torn Societies, Geneva: International Committee of the Red Cross, ICRC, 1994, p 8. 
7. See for instance, Mackinlay, J, and Alao, A, Liberia 1994: ECOMOG and UNOMIL Response to a Complex Emergency, Tokyo: The United nations University, Occasional paper Series, No.1, 1995, pp1-65.

8. UNRISD, States of Disarray, $\mathrm{p} 8$.

9. Cohen I. And Goodwill-Gills, Child Soldiers, Geneva: ICRC, 1993, p17.

10. Aneshensel, C.C. "Social Stress: Theory and Research", Annual Review of Sociology, 18, pp15-38.

11. Human Rights Watch: Easy Prey: Child Soldiers in Liberia, New York, Human Rights Watch, 1994.

12. Human Rights Watch: Easy Prey: Child Soldiers in Liberia.

13. Key Informant, Monrovia, Liberia, December, 1998.

14. Focus Group Discussion with Women including mothers of child soldiers, in Monrovia, November, 1998.

15. Interviews with opinion leaders, and discussions with key informants

16. See for instance, Gus Liebenow, Liberia: The Evolution of Privilege, , Ithaca: Cornell University, 1964, and G. W. Clower et al, Growth Without Development, Evanston, Northwestern University Press, 1966, and Amadu Sesay, "Historical Background to the Liberian Crisis," in Margaret Vogt (ed.) The Liberian crisis and ECMOG: A Bold Attempt at Regional Peacekeeping, Lagos: GABUMO Publishers, 1992, Chapter 1.

17. Interviews with child soldiers.

18. Interviews with Child Soldiers and Focus Group Discussions in Monrovia.

19. Interviews with key informants. It is interesting to note that two of the researchers were "stuck up" in a busy fast food restaurant in down town Monrovia during the field work, and had to literally "buy their way" out a potentially dangerous situation after which they hurriedly hailed a taxi to their hotel rooms

20. Interviews in Monrovia, December 1998. The researchers were taken round the complex to see for themselves the extent of the damage done to the complex during the looting spree.

21. Interviews with Directors as well as counsellors at rehabilitation centres in Monrovia.

22. Interviews with opinion leaders in Monrovia, November-December, 1998.

23. Focus Group Discussion with women and mothers of child soldiers.

24. Focus Group Discussion with mothers of child soldiers.

25. Interviews with school proprietors, principals and teaches in Monrovia, November 1998.

26. Interviews with peers of child soldiers in Monrovia.

27. This perception is reproduced in a piece of artwork by some rehabilitated child soldiers at CAP during an end of year exhibition, which the researchers attended in early December 1998. The work depicted a tearful map of Liberia being pushed into the ocean by a group of fighters comprising mainly youths, while an elderly rich man clutched US dollars watched from behind. The work 
is captioned: Thank God for ECOMOG. The researchers were so impressed they bought the work and took it home to Nigeria. It is now in the Board Room of their Centre for Derelopment and Conflict Management Studies, CEDCOMS, in Ile-Ife, Nigeria.

28. Interviews with peers of child soldiers.

29. Interview with government minister, Monrovia, Liberia, November 1998.

30. Interview with government minister.

31. Interview with government minister.

32. November 28, 1998, Monrovia.

33. Interview with key informant.

34. Interview with key informant.

35. Interview with key informant

36. Interview with key informant.

37. However, we should hasten to point out that the UK based Save the Children Fund was also involved in rehabilitating child soldiers in Monrovia. But at the time of the fieldwork, they had closed their Monrovia centres although those in other parts of the country were open. All the same, we interviewed the Programme Co-ordinator and the field officer in Monrovia. The interviews revealed that the problems faced by the centres are more or less the same.

38. Part of data in this section were obtained from a two page handout titled: Don Bosco Homes: Profile, Monrovia, no date.

39. Don Bosco Homes: Profile, pl.

40. Don Bosco Homes, Profile, p1

41. Don Bosco Homes, Profile, pl

42. Don Bosco Home, Profile, pl

43. Don Bosco Homes, Profile, p 2.

44. Interview with Reverend Father Joe Glakin, Monrovia, November, 1998.

45. Interview with Reverend Father Joe Glakin, Monrovia, and Directors at Don Bosco Centres in Monrovia.

46. The situation has remained the same since then, and although he had promised the residents of Monrovia that he would provide them with light before the year 2000, he has had to go back on his promise as the city has remained dark.

47. Don Bosco Homes, p2

48. Don Bosco Homes, $p 3$.

49. CAP: Brief Notes, Monrovia, no date, p1.

50. CAP: Brief Notes, p3.

51. See Note 27 for more on these impressions.

52. Interview with CAP Senior Director, December 2, 1998.

53. Interview with Senior Director.

54. Interview with Senior Director. 
55. Interview with Senior Director.

56. Interviews with directors, December 1998.

57. Interview with Senior Director at CAP. Interview with directors at CAP.

58. Interviews with directors, December 1998.

59. Interview with Senior Director.

60. Interview with Senior Director.

61. Interviews with directors at CAP.

62. Interviews with directors at CAP.

63. Interview with Senior Director.

64. The researchers are convinced that Liberia under Charles is a shadow state, a phenomenon which has had adverse effects not only on the rehabilitation of child soldiers, but on the majority of country's population.

65. Interviews and discussions with key informants.

66. Key informants

67. Key informants.

68. Interviews with opinion leaders, focus group discussions and key informants.

69. It was popular talk in Monrovia in November-December 1998 that Charles Taylor used his position as president to collect cash from three government agencies totalling over one million US dollars to attend the Franco-African summit in Paris in November that year. The agencies are the Liberian Maritime Authority, the Liberian External Telecommunications, and the Liberian Ports Authority. Significantly, these agencies transact many of their businesses in foreign currencies.

70. General Abacha's government in Nigeria came to a disgraceful and untimely end in June 1998, with the sudden death of the dictator, in spite of death squads. His death was widely celebrated in many parts of the country.

71. See Barry Munslow, "Angola: the search for peace and reconstruction", in Oliver Furley and Roy May (eds.), Peacekeeping in Africa, Aldershot: Ashgate, 1998). 


\section{APPENDIX 1: PERSONAL HABITS OF CHILD SOLDIERS (BEFORE, DURING, AND AFTER THE WAR).}

\section{TAB.1 DRUG USE}

\begin{tabular}{|l|ll|ll|ll|ll|ll|}
\hline & 1 & $(\%)$ & 2 & $(\%)$ & 3 & $(\%)$ & 4 & $(\%)$ & \multicolumn{2}{|c|}{ Total (\%) } \\
\hline Before & 3 & 42.86 & 1 & 14.29 & 1 & 14.29 & 2 & 28.57 & 07 & 100 \\
\hline During & 5 & 71.43 & 1 & 14.29 & 0 & 0 & 1 & 14.29 & 07 & 100 \\
\hline After & 4 & 57.14 & 0 & 0 & 2 & 28.57 & 1 & 14.29 & 07 & 100 \\
\hline
\end{tabular}

\section{TAB.2 ALCOHOLISM}

\begin{tabular}{|l|ll|ll|ll|ll|ll|}
\hline & 1 & $(\%)$ & 2 & $(\%)$ & 3 & $(\%)$ & 4 & $(\%)$ & \multicolumn{2}{|c|}{ Total (\%) } \\
\hline Before & 3 & 42.86 & 0 & 0 & 0 & 0 & 4 & 57.14 & 07 & 100 \\
\hline During & 457.14 & 0 & 0 & 0 & 0 & 3 & 42.86 & 07 & 100 \\
\hline After & 342.86 & 0 & 0 & 0 & 0 & 4 & 57.14 & 07 & 100 \\
\hline
\end{tabular}

\section{TAB.3 VISITING CSWs}

\begin{tabular}{|l|ll|ll|ll|ll|ll|}
\hline & 1 & $(\%)$ & 2 & $(\%)$ & 3 & $(\%)$ & 4 & $(\%)$ & \multicolumn{2}{|c|}{ Total (\%) } \\
\hline Before & 3 & 42.86 & 0 & 0 & 0 & 0 & 4 & 57.14 & 07 & 100 \\
\hline During & 3 & 42.86 & 1 & 14.29 & 0 & 0 & 3 & 42.86 & 07 & 100 \\
\hline After & 3 & 42.86 & 0 & 0 & 1 & 14.29 & 3 & 42.86 & 07 & 100 \\
\hline
\end{tabular}

TAB.4 EATING

\begin{tabular}{|l|ll|ll|ll|ll|ll|}
\hline & 1 & $(\%)$ & 2 & $(\%)$ & 3 & $(\%)$ & 4 & $(\%)$ & \multicolumn{2}{|c|}{ Total (\%) } \\
\hline Before & 6 & 85.71 & 1 & 14.29 & 0 & 0 & 0 & 0 & 07 & 100 \\
\hline During & 4 & 57.14 & 2 & 28.57 & 1 & 14.29 & 0 & 0 & 07 & 100 \\
\hline After & 5 & 71.43 & 1 & 14.29 & 1 & 14.29 & 0 & 0 & 07 & 100 \\
\hline
\end{tabular}

\section{TAB.5 GANGSTERING}

\begin{tabular}{|l|ll|ll|ll|ll|ll|}
\hline & 1 & $(\%)$ & 2 & $(\%)$ & 3 & $(\%)$ & 4 & $(\%)$ & \multicolumn{2}{|c|}{ Total (\%) } \\
\hline Before & 3 & 42.86 & 1 & 14.29 & 0 & 0 & 3 & 42.86 & 07 & 100 \\
\hline During & 5 & 71.43 & 1 & 14.29 & 0 & 0 & 1 & 14.29 & 07 & 100 \\
\hline After & 5 & 71.43 & 1 & 14.29 & 0 & 0 & 1 & 14.29 & 07 & 100 \\
\hline
\end{tabular}

TAB.6 RAPE

\begin{tabular}{|l|ll|ll|ll|ll|ll|}
\hline & 1 & $(\%)$ & 2 & $(\%)$ & 3 & $(\%)$ & 4 & $(\%)$ & \multicolumn{2}{|c|}{ Total (\%) } \\
\hline Before & 1 & 14.29 & 1 & 14.29 & 0 & 0 & 5 & 71.43 & 07 & 100 \\
\hline During & 2 & 28.57 & 1 & 14.29 & 0 & 0 & 4 & 57.14 & 07 & 100 \\
\hline After & 1 & 14.29 & 2 & 28.57 & 0 & 0 & 4 & 57.14 & 07 & 100 \\
\hline
\end{tabular}

\section{Scale for ranking}

$\begin{array}{lll}\text { Very high } & =1 & \text { Low }=3 \\ \text { None } & =4 & \text { High }=2\end{array}$

Key: CSWs $=$ Commercial $\_$Sex Workers 


\section{POLITICAL MAP OF LIBERIA}

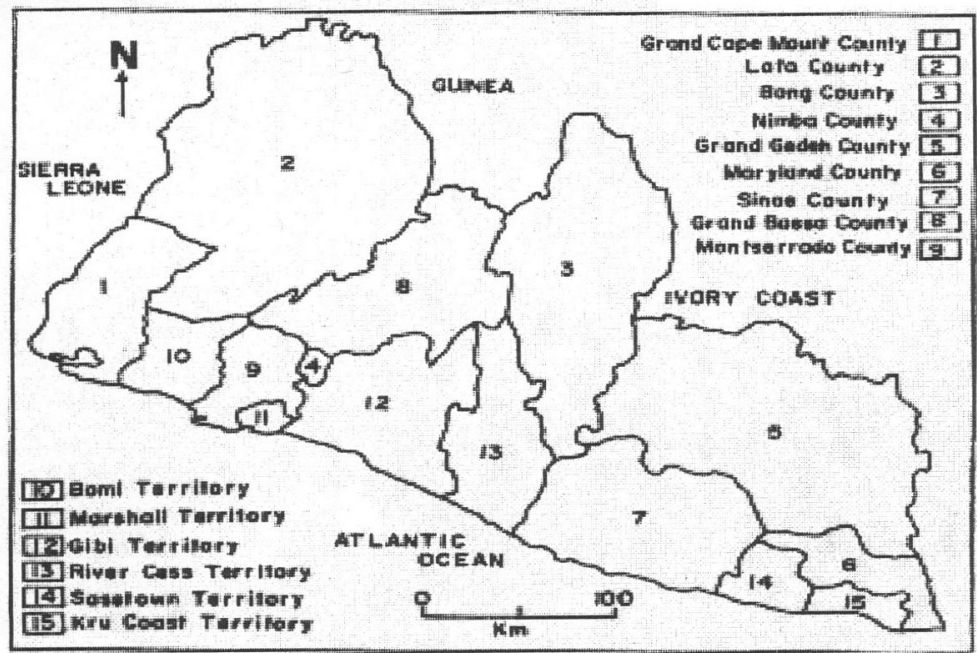

